\title{
Leaf anatomy and micromorphology of six Posoqueria Aublet species (Rubiaceae)
}

\author{
Anatomia e micromorfologia foliar de seis espécies de Posoqueria Aublet (Rubiaceae)
}

\author{
Rosani do Carmo de Oliveira Arruda ${ }^{1}$, Doria Maria Saiter Gomes ${ }^{2}$ \\ Aline Carvalho de Azevedo ${ }^{1,3}$, Michelle Lima Magalhães ${ }^{1,3}$ \& Mario Gomes ${ }^{4}$
}

\begin{abstract}
The present study deals with the leaf anatomy and leaf surface of Posoqueria acutifolia Mart., P. latifolia Mart., $P$. longiflora Aublet, P. macropus Mart., P. palustris (Rudge) Roem. and Posoqueria sp., collected in fragments of Atlantic rain forest, Rio de Janeiro, Brazil. The epicuticular wax may occur in the form of filaments, granules or crusts. The leaves are covered by a thick cuticular layer that may be smooth or striated. Paracytic stomata, and non-glandular trichomes are limited to the abaxial surface; the latter are numerous in P. palustris, and rare in P. longiflora and $P$. latifolia. Leaves have a dorsiventral structure, with only one layer of palisade parenchyma and varied amounts of spongy parenchyma. Idioblasts containing crystalliferous sand were observed, and were more abundant in P. latifolia. The leaf blade vascular system is formed by collateral bundles with a parenchymatous sheath, associated with fibers. The vascular system of the petiole and the leaf blade forms an arch. Some of the anatomical features observed can be used to distinguish the species studied. Anatomical leaf characters could be used in the recognition of six species of Posoqueria studied, such as anticlinal wall of epidermal cells, wax deposition, trichomes and shape of the leaf margin. Key words: leaf anatomy, scanning electron microscopy, taxonomy, Cinchonoideae.

Resumo

São apresentadas informações sobre a anatomia e a superficie foliar de Posoqueria acutifolia Mart., $P$. latifolia Mart., $P$. longiflora Aublet, P. macropus Mart., P. palustris (Rudge) Roem e Posoqueria sp., espécies ocorrentes em fragmentos da Floresta Pluvial Atlântica, Rio de Janeiro, Brasil. A cera epicuticular pode ocorrer na forma de filamentos, grânulos ou crostas. As folhas são recobertas por espessa camada cuticular, que pode ser lisa ou estriada. Na face abaxial a cutícula apresenta-se estriada em $P$. latifolia e $P$. palustris. Os estômatos estão restritos à face abaxial e são do tipo paracítico. Tricomas tectores ocorrem apenas nesta face sendo numerosos em $P$. palustris, raros em $P$. longiflora e $P$. latifolia. As folhas têm estrutura dorsiventral, com apenas uma camada de parênquima paliçádico e variado número no parênquima esponjoso. No mesofilo foram observados idioblastos contendo areia cristalífera, mais abundantes em $P$. latifolia. Na lâmina foliar o sistema vascular é formado por feixes do tipo colateral, envolvidos por bainha parenquimática, e apresentam fibras associadas. No pecíolo e na nervura principal o sistema vascular apresenta-se em arco. Características anatômicas foliares podem ser usadas na distinção das seis espécies de Posoqueria estudadas, tais como: a parede anticlinal das células epidérmicas, deposição de cera, tricomas e a forma da margem da folha.

Palavra-chave: anatomia foliar, microscopia eletrônica de varredura, taxonomia, Cinchonoideae.
\end{abstract}

\section{Introduction}

Rubiaceae (Gentianales) is one of the four largest families of angiosperms, with representatives widely distributed worldwide, presenting diverse habits and life forms. The family is monophyletic and includes about 10.700 species, which were recently divided into two subfamilies, the Cinchonoideae and the Rubioideae (Robbrecht \& Manen 2006).

Belonging to Cinchonoideae subfamily, Posoqueria Aublet is found in the Neotropic region and is composed of approximately 14 species that

\footnotetext{
' Universidade Federal do Estado do Rio de Janeiro (UNIRIO), Instituto de Biociências, Depto. Botânica, Av. Pasteur 458, 22290-540, Rio de Janeiro, RJ. Autora para correspondência: rosaniarruda@gmail.com

${ }^{2}$ Universidade Federal Rural do Rio de Janeiro (UFRRJ), Instituto de Biologia, Depto. Botânica, Rod. 465, km 7, 23890-000, Seropédica, RJ.

${ }^{3}$ Iniciação Científica.

${ }^{4}$ Extracta Moléculas Naturais S.A., Av. Carlos Chagas Filho 791, Cidade Universitária, 21941-904, Rio de Janeiro, RJ.
} 
are difficult to be recognized in vegetative state and present great morphological similarity (Macias 1988). To Brazil, six species are described (Macias 1988); most of them are endangered (Leonhardt et al. 2008). Some species of this group are used as ornaments, because of their decorative leaves and perfumed flowers. Most species of Posoqueria display the characteristic pollen catapult mechanism, which is the trademark feature of the Posoquerieae (Delprete 2009). According to Ariza et al. (2007), indolic alkaloids, iridoids, and acetates of hexanile and hexile, among other compounds, have been identified as perfume sources in Posoqueria latifolia (Rudge) Roem., popularly known as "açucena-do-mato". For $P$. acutifolia Mart., laboratory tests have identified analgesic and anti-inflammatory activities of the methanolic extracts, which may be related to this species use in popular medicine (Souza et al. 2007).

Among the organs that can be useful to taxonomic propositions, the leaf is the most examined one because of its internal architecture, which is a classic source of useful information in the systematics, specially the epidermis and the cuticle (Stuessy 1990; Judd et al. 2009).

About micromorphology the studies of Mantovani \& Vieira (1993/1997) and Kocsis et al. (2004) stand out and are source of important information about the leaf surface of diverse species of this family. Descriptive anatomical studies of the vegetative or reproductive parts also have been carried out with other Brazilian rubioid species (Mantovani et al. 1995; Gomes et al. 2000; Arruda \& Gomes 1996. De Toni \& Mariath 2008).

This study describes the leaf anatomy and micromorphology of six Brazilian Posoqueria species: P. acutifolia Mart., P. latifolia (Rudge) Roem. \& Schult., P. longiflora Aubl., P. macropus Mart., P. palustris Mart., and Posoqueria sp. aiming to identify features that may be useful in recognizing these species.

\section{Materials and Methods}

Adult leaves of Posoqueria latifolia and $P$. longiflora were collected from plants found at the Parque Nacional da Floresta da Tijuca (22 ${ }^{\circ} 57^{\prime} \mathrm{S}$ and $43^{\circ} 18^{\prime} \mathrm{W}$ ), in Rio de Janeiro, (RJ). In this region, the annual avarage temperature varies between $19.3^{\circ} \mathrm{C}$ in the winter and $25.5^{\circ} \mathrm{C}$ in the summer, and the rainfall is about $2000 \mathrm{~mm}$ annually (Vieira 1994). Posoqueria palustris was collected in Rio das Ostras (RJ, 22 ${ }^{\circ} 31 S^{\prime}$ $41^{\circ} 55^{\prime} \mathrm{W}$ ) where the annual average temperature is $22^{\circ} \mathrm{C}$ and the annual rainfall between 1500 and $2000 \mathrm{~mm}$
(Bidegain \& Michael 2003). In this site, the plants are submitted to seasonal flooding in the rainy season, when the water table rises considerably. Posoqueria acutifolia was collected at the Parque Estadual da Serra da Tiririca, Niterói, RJ ( $22^{\circ} 48^{\prime}$ S, $\left.42^{\circ} 57^{\prime} \mathrm{W}\right)$, a fragment of the Atlantic Rain Forest. In this region the annual average temperature is $24^{\circ} \mathrm{C}$, with annual rain fall of $1300 \mathrm{~mm}$ concentred in the summer. Herborized leaves of $P$. macropus (Sucre 7678) and Posoqueria sp. (Martinelli 8804), obtained from the Instituto de Pesquisas Jardim Botânico do Rio de Janeiro (RB), were rehydrated according to Gomes (2002).

The fresh leaves were fixed in F.A.A. (formalin, acetic acid, ethanol 70\%) for $48 \mathrm{~h}$ and preserved in $70 \%$ ethanol (Johansen 1940). For light microscopy, sections of the leaf blade and petiole were dehydrated in graded ethanol-butanol series, embedded in paraffin, sectioned transversely and longitudinally in rotatory microtome at a thickness of $12 \mathrm{~mm}$. The sections were stained with $1 \%$ safranin - $1 \%$ astra blue in tartaric acid (Luque et al. 1996).

The epidermis was studied using sections of the leaf blade dissociated in acetic acid/hydrogen peroxide (Franklin 1945) The epidermis was stained with $1 \%$ safranin, alcian blue, or $0.5 \%$ fuchsin (modifications in Kraus \& Arduin 1997). In order to remove wax and to confirm its presence, sections of herborized leaves were boiled in chloroform three times for one minute, on a hot plate. For the scanning electron microscopy (SEM) analysis, leaf pieces were critical-point dried through a graded series of ethyl alcohols. Leaf fragments were mounted on stubs coated with gold and observed in a JEOL JSM-5310 scanning electronic microscope. Material from herbarium was also mounted on proper stubs coated with gold before being observed in the SEM.

For the histochemical tests, freehand sections of leaf blade were treated with the following reagents: starch grains were localized by Lugol staining (Johansen 1940), lipidic compounds were recognized by Sudan Red 7B in glicerol/ethanol (Kraus \& Arduin 1997), pectin substances with $0.02 \%$ ruthenium red (Kraus \& Arduin 1997); primary walls were identified with zinc iodine chloride (Jensen 1962) and the secondary walls with acid phloroglucin for lignified cells (Foster 1949); phenolic compounds were confirmed with ferric chloride (Johansen 1940). Tests with hydrochloric acid were used to detect calcium oxalate crystals (Jensen 1962). 


\section{Results}

In most of the studied species, the epidermis, in adaxial surface is composed of ordinary epidermal cells, with sinuous anticlinal walls (Fig. 1 a-f), and thick, notably in Posoqueria macropus (Fig. $1 \mathrm{~d}$ ). Over vascular bundles, such as in the abaxial surface of Posoqueria sp. the anticlinal walls can present themselves straight or curved (Fig. 1 f). The abaxial surface is composed by ordinary epidermal cells, stomata and trichomes (Fig. 2 a-f). The epidermal anticlinal cells walls are sinuous in all species (Fig. 2 a-e), with the exception of Posoqueria sp in which they are straight. $P$. acutifolia has glabrous leaves (Fig. 2 a), in P. macropus numerous, non-glandular, unicellular trichomes, with thick lignified walls were observed (Fig. 2 d). In P. palustris there are pluricellular uniseriated trichomes, long, non lignified (Fig. 2 e). Posoqueria sp is marked by presence of numerous papillae (Fig. 2 f). Rare short unicellular non-glandular trichomes are observed on the abaxial surface of the leaf of $P$. latifolia and $P$. longiflora, restricted to midvein; in $P$. palustris, numerous pluricellular trichomes are observed.

The stomata belong to the paracytic type and are arranged randomly (Fig 2). The subsidiary cells may be of different sizes; some stomata may be flanked in parallel by more than one subsidiary cell. The six species investigated present some large stomata, around which the epidermal cells are organized radially, and the cuticle layer forms a radiate pattern (Fig. 2 b). In P.macropus and P. palustris the stomata are partly covered by numerous trichomes (Fig. 2 d-e).

The epicuticular wax can occur without defined ornamentation, in the form of filaments, granules and in crusts (Figs. 3 a-h, $4 \mathrm{a}-\mathrm{g}$ ). The granules can be of varied sizes and are present in Posoqueria acutifolia (Fig. 4a), P. longiflora (Fig. 3 d, 4d), P. macropus (Fig. 4 e), P. palustris (Fig. 4 f) and Posoqueria sp (Fig. 4 g), including over the stomata (Fig. 4 d, g) and trichomes (Fig. 4 e). The crusts occur in P. macropus (Fig. $3 \mathrm{f}$ ), $P$. palustris (Fig. $3 \mathrm{~g}$ ) and are thick in $P$. latifolia (Fig. 3 b); the filaments occur in abaxial surface of $P$. latifolia (Fig. 4 c). The cuticle is smooth on the adaxial surface of all species (Fig. $3 \mathrm{a}-\mathrm{h}$ ) and on the abaxial surface of $P$. longiflora (Fig. $4 \mathrm{~d}$ ), and striated on the abaxial surface of the other species (Fig. 4 b, e-g), specially in P. latifolia (Fig. 4 c) and in Posoqueria sp (Fig. 4 g).

In all species investigated the leaf epidermis is one-layred formed by thick-walled cells and covered by a layer of cuticle and well-developed cuticular-wax strata (Fig 5 a-d). On the abaxial surface, above the stomatal pore, the cuticle layer may form conspicuous ledges (Fig. $5 \mathrm{c}$ ). The stomata are located on the same level or slightly below the other epidermal cell and the subsidiary cells can form projections in the region of the substomatal chamber (Fig. 5 c). The trichomes have thick walls (Fig. 5 b), and in Posoqueria palustris, the basal region of the septate trichome is pitted (Fig. $5 \mathrm{~d}$ ).

All the species studied show dorsiventral mesophyll, with one layer of cells in the palisade parenchyma and about 10 to 14 layers in the spongy parenchyma (Fig. 6 a-e). The palisade cells are wider and shorter in Posoqueria acutifolia and P. latifolia (Fig. 6 a-b) and longer and narrower in the remaining species (Fig. 6 c-e). Idioblasts containing tiny polyhedral crystals of calcium oxalate (crystalliferous sand) are observed on the entire mesophyll in all species studied (Fig. $6 \mathrm{c}, \mathrm{f}$ ). They are more abundant in $P$. latifolia and $P$. palustris. These cells occur in a greater frequency beneath the palisade parenchyma, or near the epidermis of the abaxial surface, isolated or in groups, especially in $P$. latifolia and $P$. palustris (Fig. 6 e-f). The histochemical tests showed that the crystalliferous cells also accumulate phenolic compounds.

The vascular system of the leaf blade is formed by bundles of the collateral type, of varied calibers (Fig. 6 a, d). The vascular bundles are surrounded by a parenchymatous sheath that may contain chloroplasts, crystalliferous sand, and phenolic compounds. Internally to this sheath lignified fibers occur in variable proportions. In Posoqueria acutifolia, P. latifolia and P. macropus the sclerenchyma occurs in a larger proportion than the vascular tissues (Fig. 6 a, d).

The cross section showed that the outline of leaf margin is truncate-revolute in Posoqueria longiflora and slightly revolute in the others species (Fig. 7 a-d). In the epidermis, characteristics similar to those of the rest of the leaf blade can be observed, noticing that the cuticular layer is strongly thickened, forming conspicious cuticular flanges. The common epidermal cells are smaller then in the rest of the leaf blade and in P. longiflora have a papillose appearance. Internally, the margin is filled with parenchymatous cells with thickened walls; among them idioblasts with crystals occur. Lignified fibers were observed associated to the vascular system.

In transversal section the outline of petiole can be sulcate, plan-convex or concave-convex (Fig. $8 \mathrm{a}-\mathrm{c})$. On the petiole and along of the midvein, on 

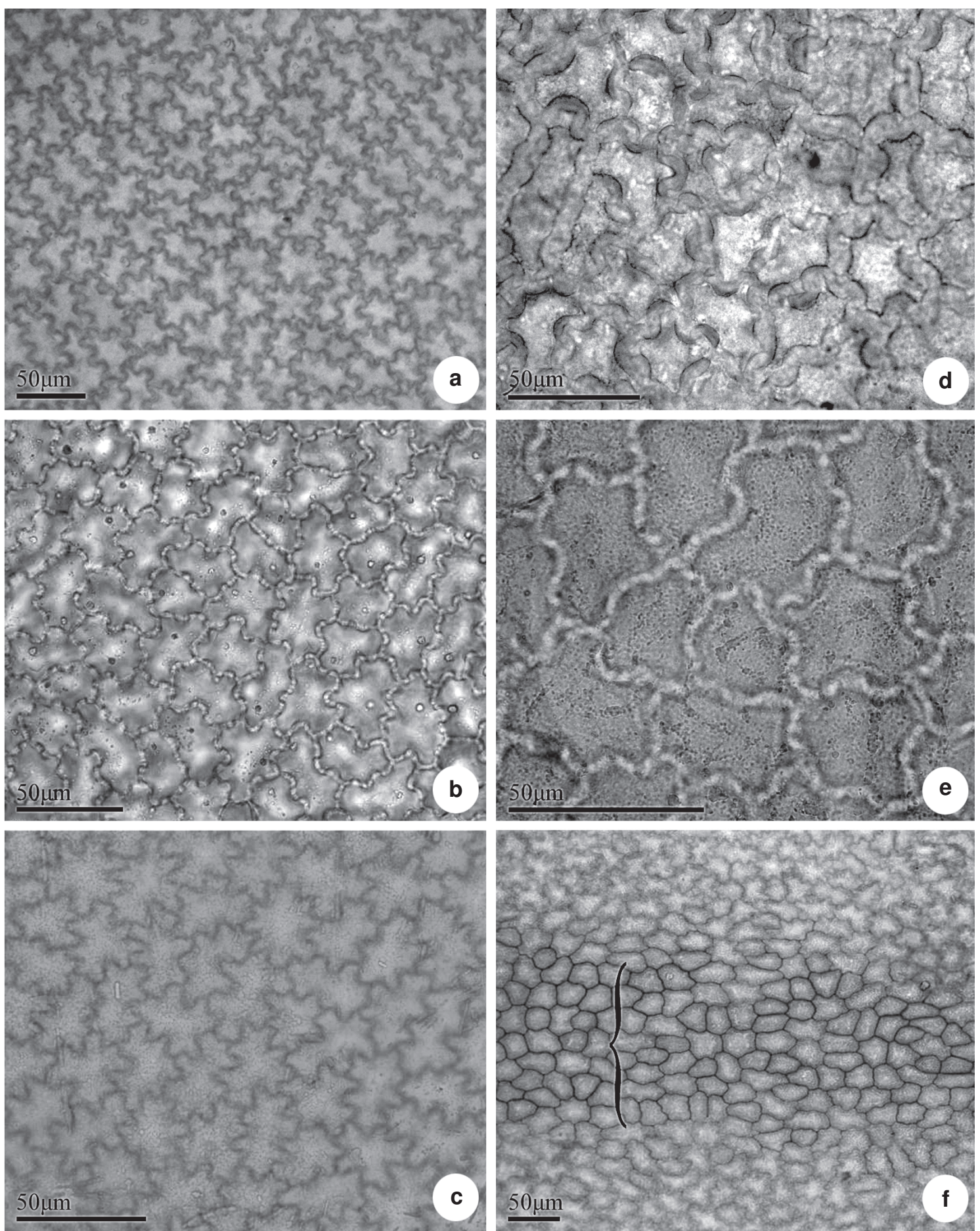

Figure 1 - Leaf epidermis of Posoqueria Aublet in frontal view, adaxial surface - a. P. acutifolia; b. P. latifolia; c. P. longiflora; d. P. macropus; e. P. palustris; f. P. longiflora, in the midvein region ( \{) . 

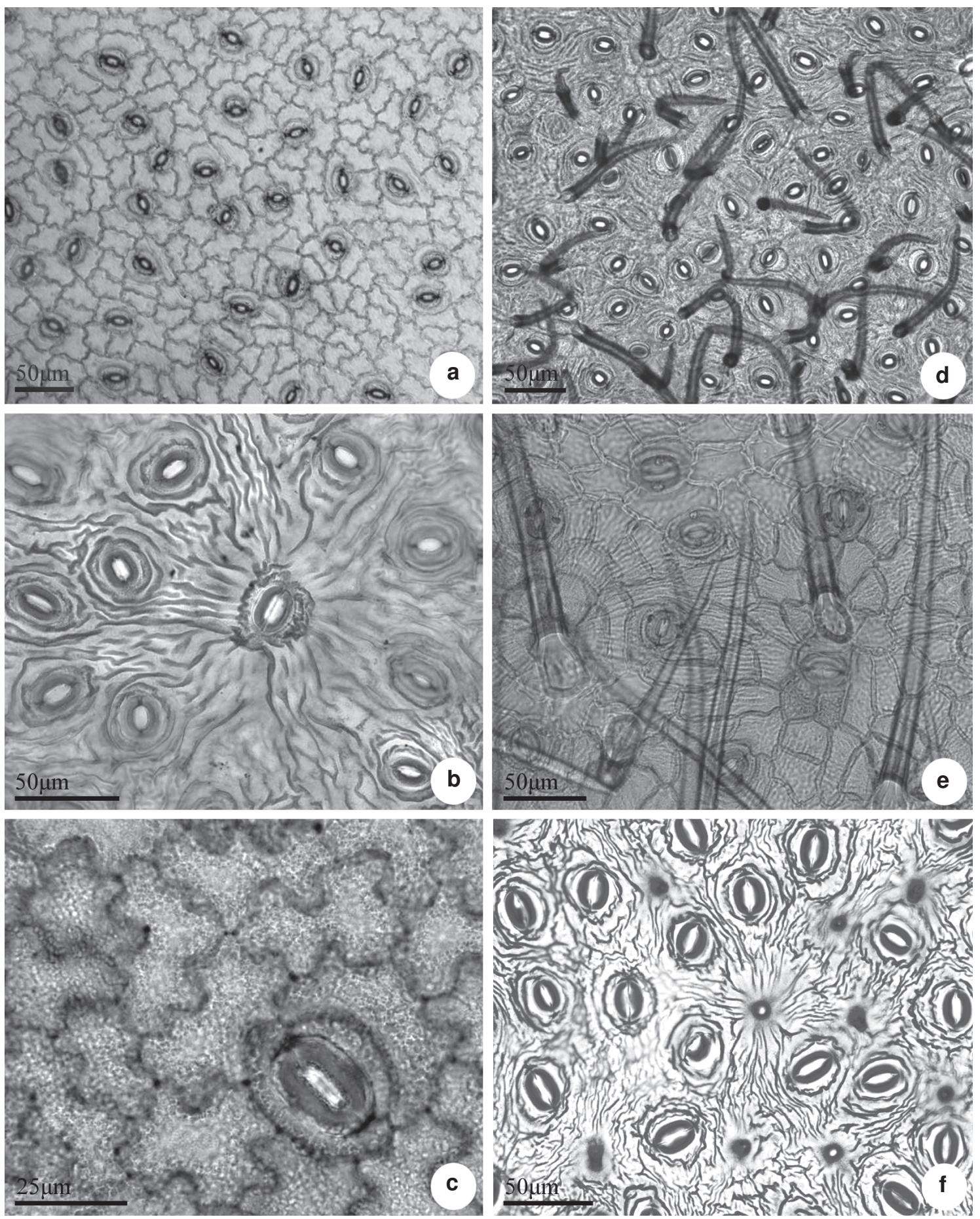

Figure 2 - Leaf epidermis of Posoqueria Aublet in frontal view, abaxial surface-a. P. acutifolia; b. P. latifolia; c. P.longiflora; d. P. macropus; e. P. palustris; f. Posoqueria sp. showing the the arrangement of stomata, trichomes (d, e) and papillae (f). 

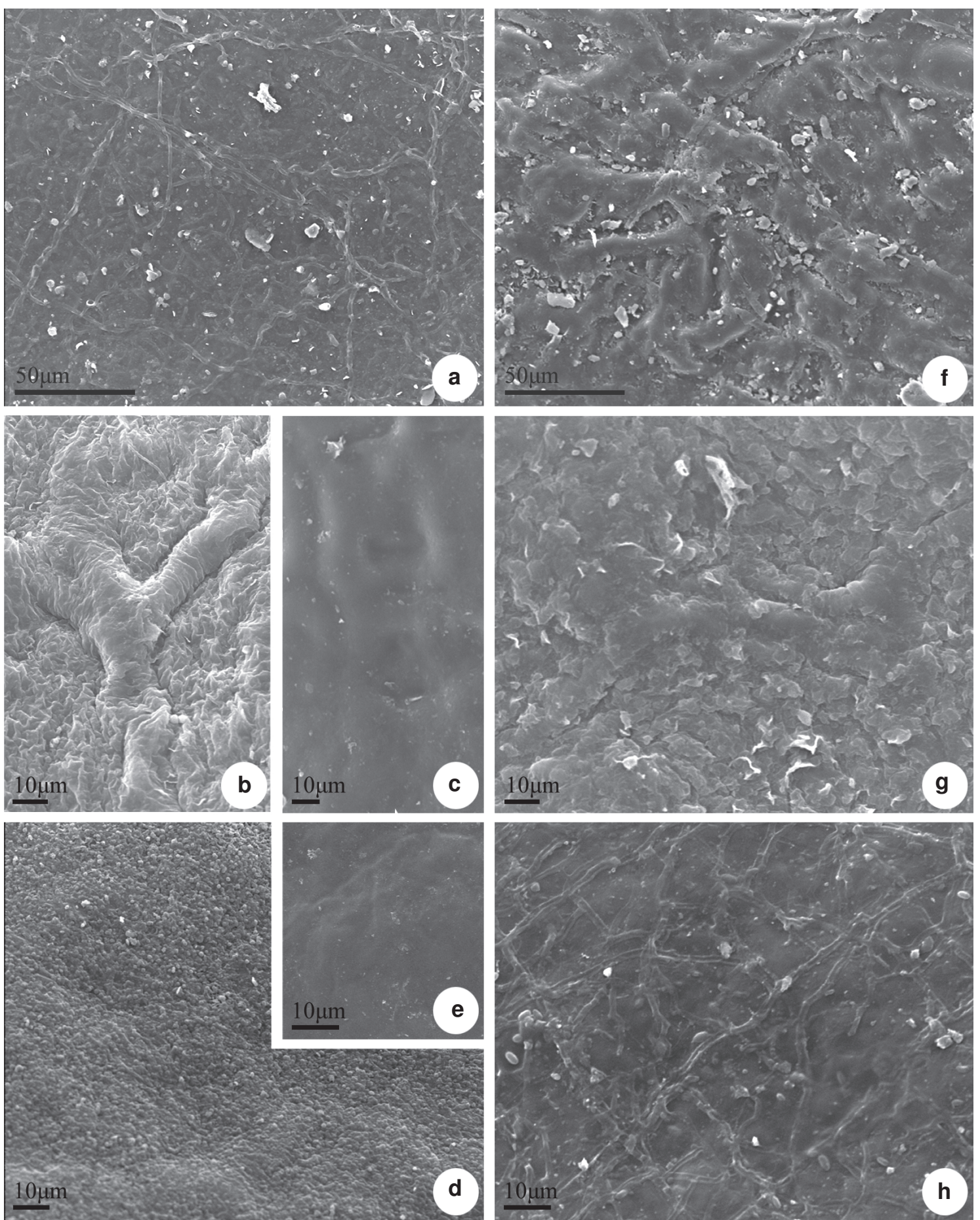

Figure 3 - Scanning electron microscopy of leaf blade of Posoqueria Aublet - a. P. acutifolia; b-c. P. latifolia; d-e. P. longiflora; f. P. macropus; g. P. palustris; h. Posoqueria sp. Adaxial surface showing wax in granules (d), in crusts (f) and in thick crusts (b). 

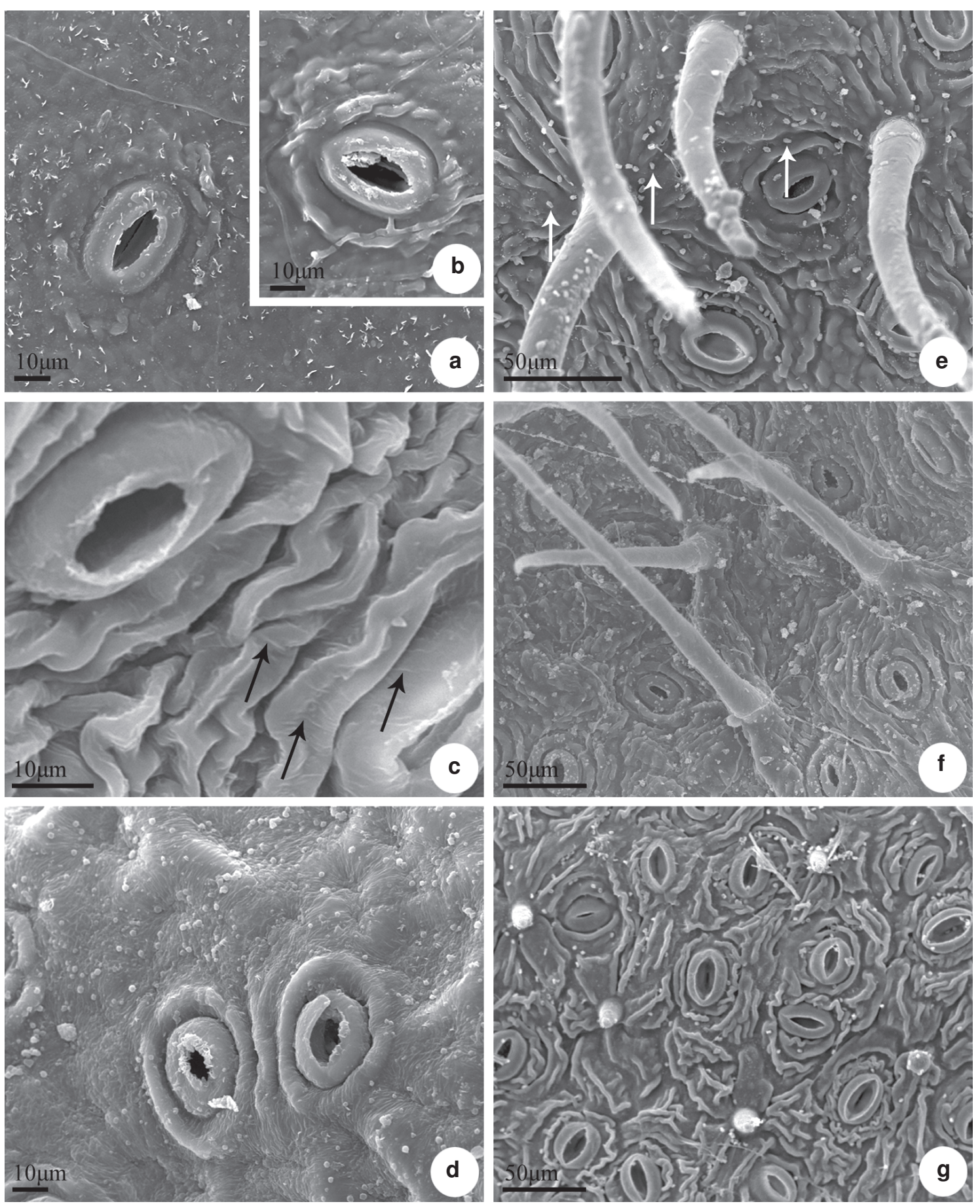

Figure 4 - Scanning electron microscopy of leaf blade of Posoqueria Aublet - a. P. acutifolia; b. P. acutifolia boiled; c. P. latifolia; d. P. longiflora; e. P. macropus; f. P. palustris; g. Posoqueria sp. Abaxial surface showing stomata (a-g), trichomes in P. macropus (e) and P. palustris (f) and papillae in Posoqueria sp. (g). The surface can be smooth (d) or striated (b-c, e-g). Epicuticular wax (arrow) in filaments (c) and granules (e). 


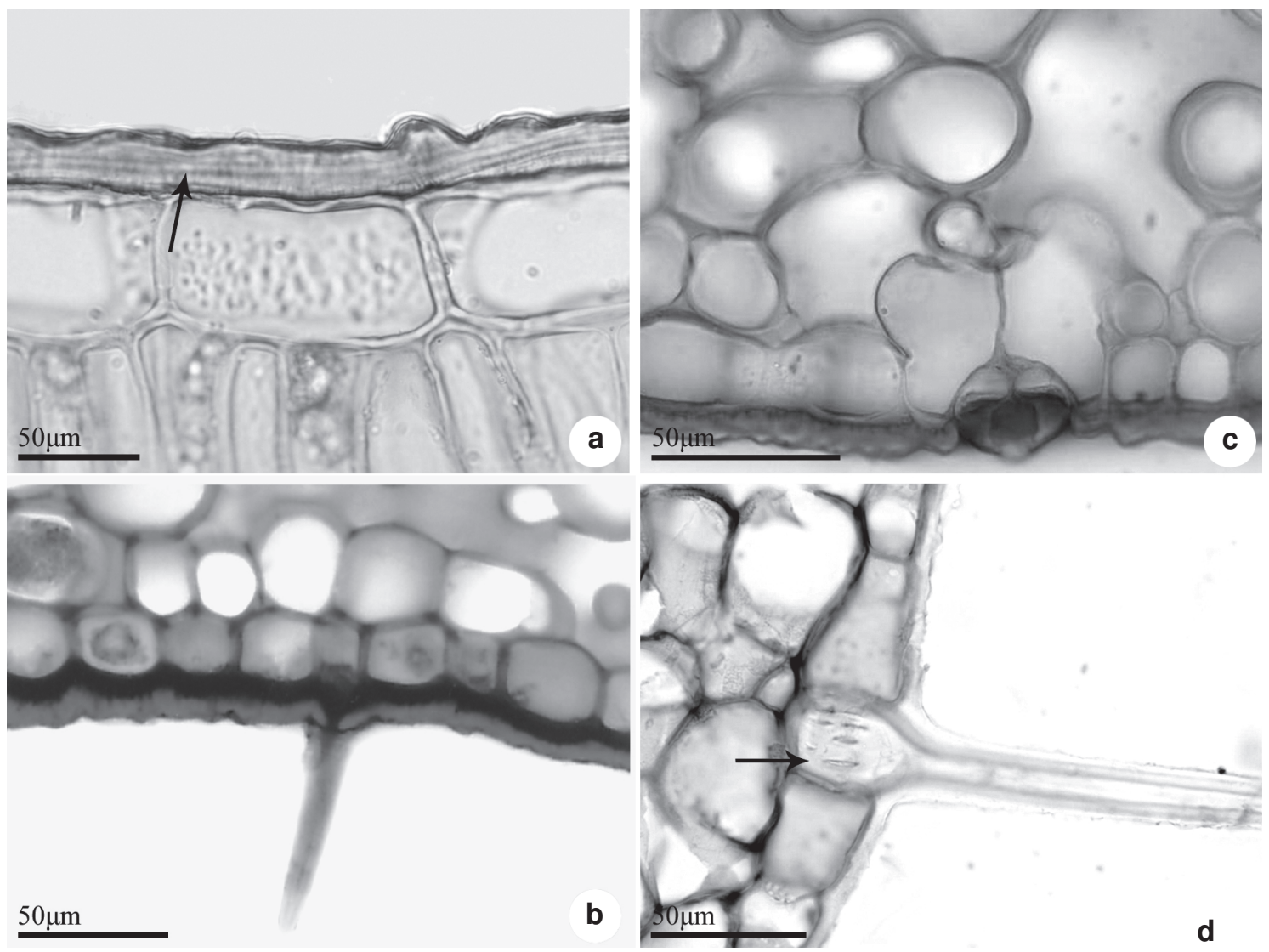

Figure 5 - Cross sections of Posoqueria Aublet leaf, details of epidermis - a. P. latifolia with a thick cuticular layer (arrow); b. P. longiflora, trichome in midvein region; c. P. longiflora, stomata with developed rims and subsidiry cells in the substomatal chamber; d. P. palustris, lignified trichome with pitted wall (arrow).

both surfaces of the leaf, the epidermal cells are organized in rows and have thicker, nearly straight walls. Stomata can be found in this region of the leaf blade. In the cortical region of the petiole there are two to five layers of angular collenchyma beneath the epidermis. A fundamental parenchyma containing idioblasts with crystals, phenols, or some sclereids are located internally (Fig. $8 \mathrm{~d}$, h). In all species, the vascular system is arranged in an $\operatorname{arch}$ (Fig. 8 a-c, e), with the xylem cells arranged in rows and the phloem in the external position, like the collateral type. Additional bundles are observed at the extremities of the vascular system.

In the region of the midvein, beneath the epidermis, the cortical region is occupied by three to five layers of collenchyma that varies between the angular and lamellar types, and underneath there is a palisade parenchyma connecting the two parts of the leaf blade (Fig. $8 \mathrm{f}-\mathrm{g}$ ). In this portion, the cells of the palisade parenchyma are shorter and wider than the remaining parts of the leaf blade. In the cortical portion below the abaxial surface there is a parenchyma which shows progressively more-voluminous cells with thinner walls towards the vascular system.

In this study the most relevant leaf characteristics to the distinguishing of the species are related in the Table 1.

\section{Discussion}

From all the anatomical features examined, the ones that showed a higher potencial of utilization to identify the studied species were: cuticular and wax sculpturing, aspect of the anticlinal walls of epidermal cells and presence and types of trichomes. The variation on the thickness em sinuosity from the anticlinal walls is quoted fot the Rubiaceae by Metcalfe \& Chalk (1950) and Gomes et al. (2000). Harberlandt (1928) believes that the 

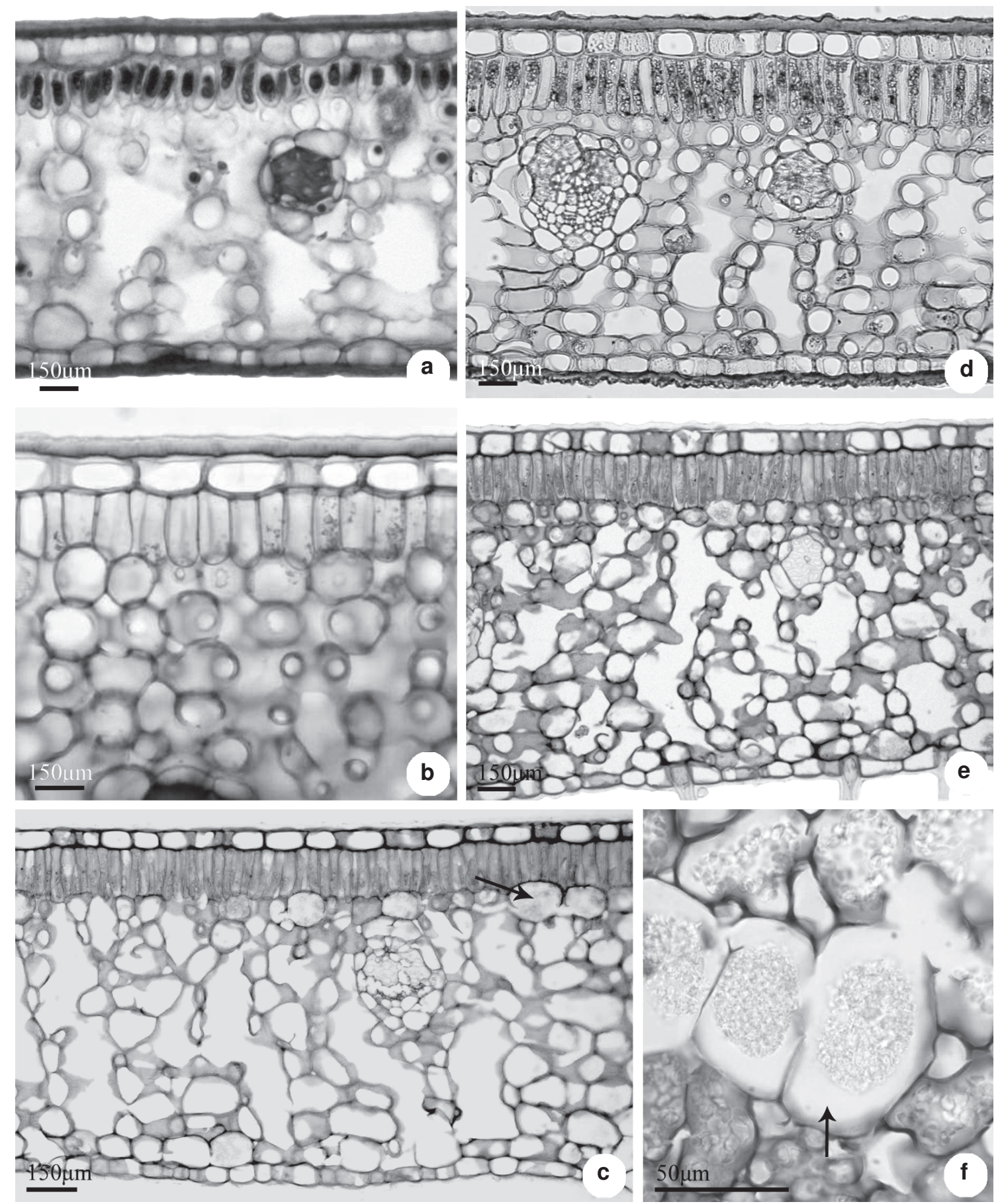

Figure 6-Cross sections of Posoqueria Aublet leaf showing the dorsiventral mesophyll structure - a. P. acutifolia; b. P. latifolia; c. P. longiflora; d. P. macropus; e. P. palustris; f. P. palustris with crystal sand in idioblasts (arrow). 

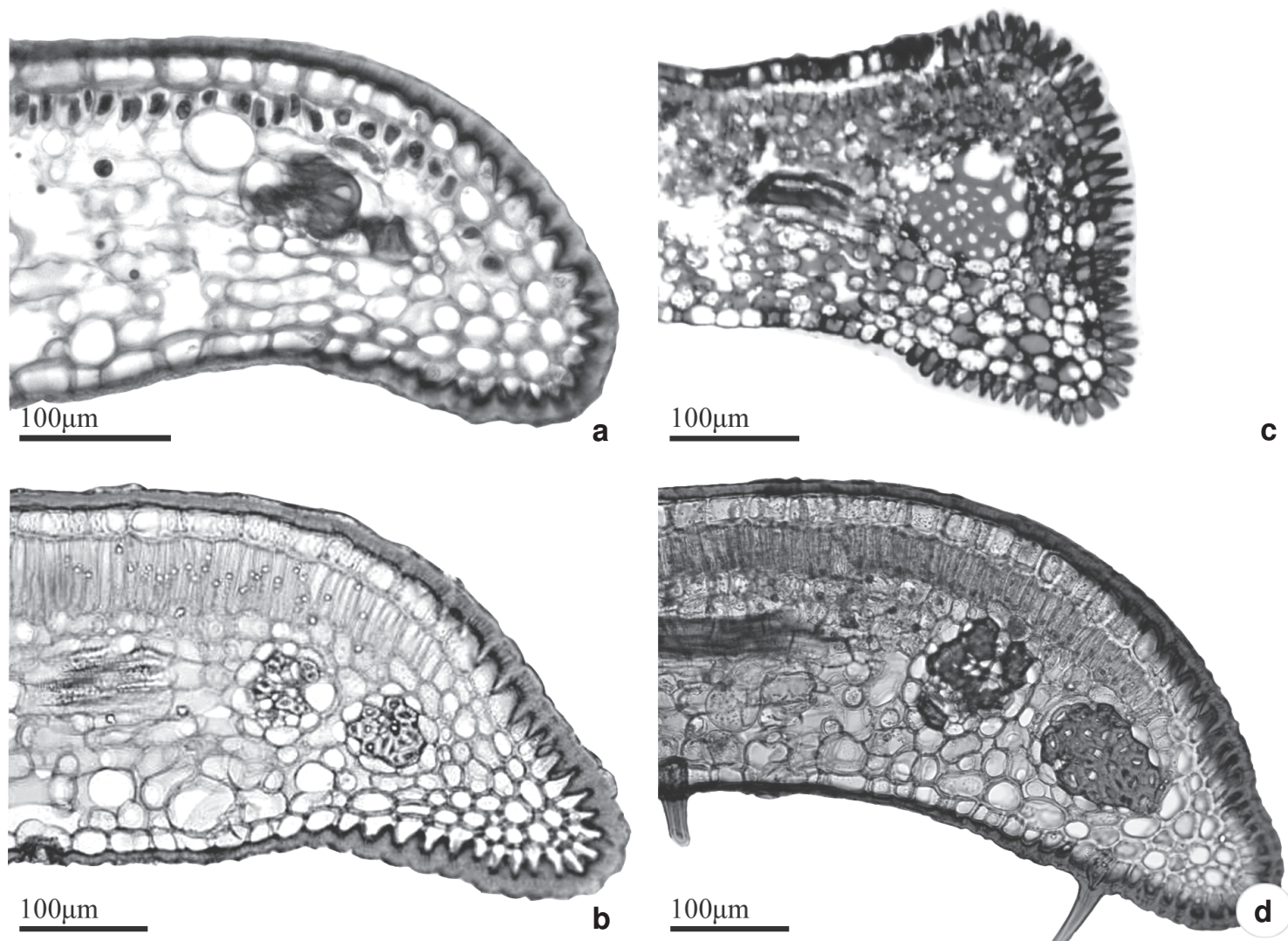

Figure 7 - Cross sections of Posoqueria Aublet showing variation outline of the leaf margin - a. P. acutifolia; b. P. latifolia; c. P. longiflora; d. P. palustris.

Table 1 - Distinctive characteres to the identification of six Posoqueria Aublet (Rubiaceae) species.

\begin{tabular}{|c|c|c|c|c|c|c|}
\hline $\begin{array}{l}\text { Characters/ } \\
\text { Species }\end{array}$ & $\begin{array}{l}\text { Posoqueria } \\
\text { acutifolia }\end{array}$ & $\begin{array}{l}\text { Posoqueria } \\
\text { latifolia }\end{array}$ & $\begin{array}{l}\text { Posoqueria } \\
\text { longiflora }\end{array}$ & $\begin{array}{l}\text { Posoqueria } \\
\text { macropus }\end{array}$ & $\begin{array}{l}\text { Posoqueria } \\
\text { palustris }\end{array}$ & $\begin{array}{c}\text { Posoqueria } \\
\text { sp. }\end{array}$ \\
\hline \multicolumn{7}{|l|}{$\begin{array}{l}\text { Epidermis, } \\
\text { adaxial surface }\end{array}$} \\
\hline $\begin{array}{l}\text { Outline of anticlinal } \\
\text { wall }\end{array}$ & sinuous & sinuous & sinuous & sinuous & sinuous & straight \\
\hline Cuticular surface & smooth & smooth & smooth & smooth & smooth & striated \\
\hline Epicuticular wax & smooth & crusts & granules & crusts & crusts & smooth \\
\hline \multicolumn{7}{|l|}{$\begin{array}{l}\text { Epidermis, } \\
\text { abaxial surface }\end{array}$} \\
\hline $\begin{array}{l}\text { Outline of } \\
\text { anticlinal wall }\end{array}$ & sinuous & sinuous & sinuous & sinuous & $\begin{array}{l}\text { straight } \\
\text { to curves }\end{array}$ & straight \\
\hline Cuticular surface & striated & striated & smooth & striated & striated & striated \\
\hline Epicuticular wax & granules & filaments & granules & granules & granules & granules \\
\hline $\begin{array}{l}\text { Form and distribution } \\
\text { of trichomes }\end{array}$ & absent & $\begin{array}{l}\text { unicellular, } \\
\text { restrict to } \\
\text { midvein } \\
\text { region }\end{array}$ & $\begin{array}{l}\text { long, } \\
\text { unicellular, } \\
\text { restrict to } \\
\text { midvein region }\end{array}$ & $\begin{array}{l}\text { long, } \\
\text { unicelular, } \\
\text { intercoastal } \\
\text { region }\end{array}$ & $\begin{array}{l}\text { long, } \\
\text { pluricelular, } \\
\text { intercoastal } \\
\quad \text { region }\end{array}$ & $\begin{array}{l}\text { papillae, } \\
\text { intercoastal } \\
\text { region }\end{array}$ \\
\hline $\begin{array}{l}\text { Outline of the leaf margin } \\
\text { in transvesal section }\end{array}$ & revolute & revolute & $\begin{array}{l}\text { truncate/ } \\
\text { revolute }\end{array}$ & revolute & revolute & revolute \\
\hline
\end{tabular}



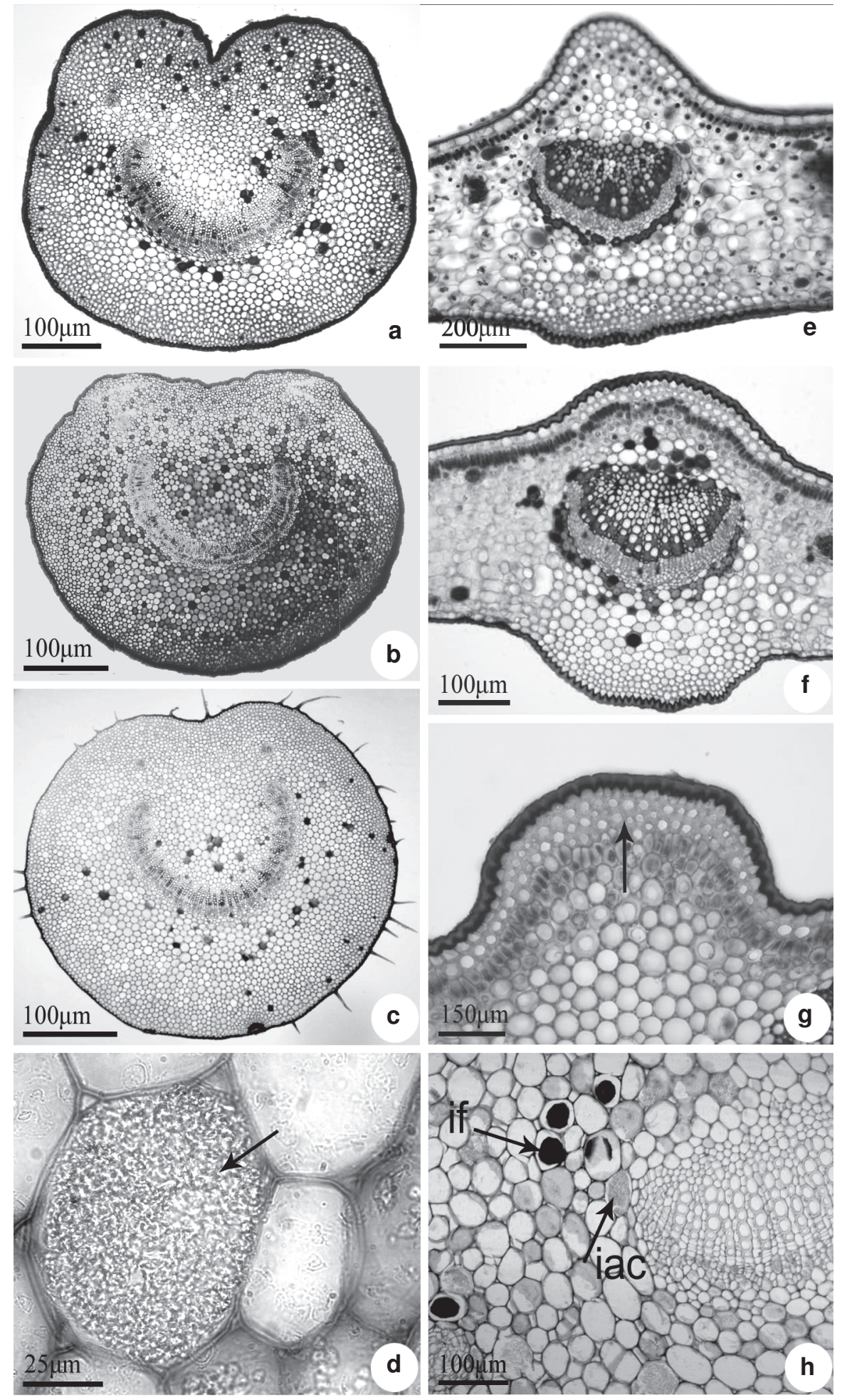

Figure 8 - Petiole and midvein of Posoqueria Aublet in cross section - a. P. latifolia; b. P. longiflora; c. P. palustris; d. P. palustris showing idioblast with crystal sand in detail (arrow). e. P. acutifolia; f. P. latifolia g. and h. P. palustris with collenchyma and palisade tissue under adaxial epidermis (g, arrow), idioblasts with phenols (if) and crystal sand (iac), on cortical region of petiole (h) 
sinuosity from the walls has an important mechanical function, increasing the rigidity of the cell to prevent the parietal collapse in case of lack of water. In Posoqueria the walls of epidermic cells that revest the vascular bundles are less sinuous than the ones that revest the mesophyll, what probably is associated to the fact that this region is less susceptible to the environment influences like the loss of water.

A thick cuticular layer is generally observed in plants of dry environment (Fahn \& Cuttler 1992). For the plants studied here, which were collected in the interior of the Atlantic Rain Forest, the thick cuticular layer, besides protecting the plants from dehydration and from invasion by fungi and bacteria, also protects them from the heavy rain that is common in the neotropics (Juniper \& Jeffree 1983). The different aspects of the cuticular layer of the abaxial surfaces and the ornamentation of epicuticular wax could be used in the characterization of these species, confirming the potencial value of this anatomical characteristics for the taxonomists (Wilkinson 1979).

The presence of hypostomatous leaves appears to be the most common case among the Rubiaceae (Metcalfe \& Chalk 1950). In all cases, paracytic stomata predominate, although other patterns such as the anomocytic or anisocytic are reported in the family (Metcalfe \& Chalk 1950). Stomata with two or more subsidiary cells arranged parallel to the stomata cells can be classified as parallelocytic, as in the species of Posoqueria studied here and also previously described by several members of Rubiaceae (Mantovani et al. 1995; Kocsis et al. 2004). According to Carpenter (2005), the anomocitic type is an ancestral condition between the basal angiosperms; besides, the paracytic stomatal architecture has been derived independently some families in this group.

Trichomes have great value in taxonomical, ecological, and evolutionary studies (Gomes \& Neves 2009). In the Rubiaceae, the leaf trichomes are of the non-glandular type, uni-or multicellular, in variable densities and sizes, from papillae to longer ones that form a dense indumentum (Metcalfe \& Chalk 1979; Gomes et al. 2000; Kocsis et al. 2004). Robbrect \& Manen (2006) proposed that whereas the Rubioideae are distinguished by having generally articulated trichomes, those of the Cinchonoideae are distinguished by the cylindrical type (unicellular), as observed in Posoqueria latifolia and P. longiflora. In P. palustris, however, the pattern does not support the proposal of these authors because this species is the only one that shows pluricellular trichomes. In the present study, the type, number of cells (uni or pluricellular) and distributions could be used to recognize the evaluted species as presented in Table 1. This result confirms the importance of these features to taxomic applications as proposed by Metcalfe \& Chalk (1979).

The thickness of the leaf blade, however, varies with the amount of light and thin leaves are common in species from the understorey, such as Psychotria nuda Wawra, P. leiocarpa Mart., Bathysa gymnocarpa K. Schum, B. mendonçaei K. Schum, B. cuspidata (A.St.-Hil.) Hook.f. and B. australis (A.St.-Hil.) Benth. \& Hook.f. among others (Vieira et al. 1992; Gomes et al. 2000). Rubiaceae in open areas, such as the coastal dune forests (restingas), has thicker leaves (Arruda \& Gomes 1996). The greater leaf thickness may be a result of accentuated development of the palisade or even the spongy parenchyma, under intense irradiation (Dickison 2006). The species of Posoqueria studied even though collected in areas where they are relatively protected by the crowns of the canopy plants, have proportionately thicker leaves as a result of the larger number of spongy parenchyma layers. Considering the plastic variation of this character, it has no taxonomic value to the identification of the analized Posoqueria species.

Calcium oxalate crystals are an important source of information for defining the subfamilies, tribes, and subtribes of Rubiaceae. Few studies about the development of these idioblasts or ontogenetic and evolutionary relationships of these cells for the subfamilies of Rubiaceae are available in the literature, except the work of Horner \& Whitmoyer (1972) with Psychotria punctata. Crystals are abundant in the family, and include crystal-sand, raphides, clustered, styloids and other acicular forms. According to Metcalfe \& Chalk (1950) the crystal distribution is helpful in genera delimitation. Recently the raphides-type crystals were said to be related to the subfamily Rubioideae, and the absence of this type and the presence of druses or crystalliferous sand, with some exceptions, characterizes the Cinchonoideae (Jansen et al. 2003; Andersson \& Antonelli 2005; Robbrecht \& Manen 2006). In the six species of Posoqueria examined, only idioblasts containing crystalliferous sand were observed, corroborating the proposed assignment for the genus. Although this study was not quantitative, it was clear that in 
$P$. latifolia the amount of idioblasts in the leaf blade is comparatively much higher than in the leaf blade of the other two species.

The arrangement of the vascular system in the petiole and the midvein can be useful in the diagnosis of some plant species. In this sense, morphological patterns have been established for taxonomic purposes dealing with several plant families. In the leaves of many Rubiaceae, the vascular tissues may be arranged in a U, O, or V-shape (Metcalfe \& Chalk 1950; Kocsis et al. 2004). The organization of the vascular system can be used in superior taxonomic levels in Rubiaceae (Martinez-Cabrera et al. 2009). In all species analyzed, the vascular system is organized in an arch from the petiole to the principal vein, where it begins to be accompanied by some fibers. For the Posoqueria analyzed, a small diagnostic value was attributed to the shape of vascular system in transversal section at species level.

Although the species of Posoqueria are considered to be typical shade plants (Macias 1988), some xeromorphic elements were identified in the leaf blade, specially in $P$. macropus e $P$. palustris. These species are eventually affected by the dry and flood periods, a trademark of the flooded region in which they were found, and show, besides the thick cuticular layer, a high amount of fibers associated to the vascular system. The xeromorphic features observed in the studied plants, especially in $P$. macropus and $P$. palustris, can be related to the coastal environment where they are found, marked by a deficiency of nitrogen, phosphorus, calcium and elevated acidity (Henriques et al. 1986). The sclerification is considered an important strategy for the survival in poor resourced places, because it gives the plants an augmentation of the longetivity and a higher efficiency in the use of available nutrients (van Arendonk \& Poorter 1994).

This study show that anatomical leaf characters could be allied to morphological ones in the recognition of six species of Posoqueria evaluated, such as, outline of anticlinal wall of epidermal cells in frontal view, the patterns of the wax and cuticle deposition, the presence and type of trichomes, and the cross-sectional shape of the leaf margin.

\section{Acknowledgments}

We want to thank the Curator of the Herbarium of Instituto de Pesquisas Jardim Botânico do Rio de Janeiro (RB) for the permission of using his collection. We want to thank Rosilene Gonçalves, Anna Carina Defaveri, Jefferson Andrade Ferrão and Ana Angélica M. de Barros for their assistance with field and laboratory work. We want to express our gratitude also to Alice Sato, Alcides Guarino and Edwin Azzero for the many laboratories facilities. To Flora Gomes Elias for English revision.

\section{References}

Andersson, L. \& Antonelli, A. 2005. Phylogeny of the tree Cinchoneae (Rubiaceae), its position in Cinchonoideae, and discription of a new genus, Liliosemina. Taxon 54: 17-28.

Ariza, O.A.; Parra, E.D.R.; Archila, J.A.; Morales, J.M. $\&$ Stashenko, E. E. 2007. Determinación mediante HS-SPNE / GC-MS, de la composición química de la fragancia y el absoluto de las flores de Posoqueria latifolia. Scientia et Technica 33: 59-61.

Arruda, R.C.O. \& Gomes, D.M.S. 1996. Anatomia Foliar de Mitracarpus frigidus (Wild). K. Shum. var Salzmannianus (D.C) K. Shum. e Mitracarpus lhotzkianus Cham. (Rubiaceae). Boletim do Herbarium Bradeanum. 6: 431-444.

Bidegain, P. \& Michael, C. 2003. Bacias hidrográficas dos Rios São João e das Ostras. Águas, Terra e Conservação Ambiental. Consórcio Intermunicipal Lagos São João (CILSJ). Available in <http:// www.lagossaojoao.org.br/index-cilsj.html >. Access on 10 August 2006.

Carpenter, K.J. 2005. Stomatal architecture and evolution in basal angiosperms. American Journal of Botany 92: 1595-1615.

De Toni, K.L.G. \& Mariath, J.E.A. 2008. Ovule ontogeny in Rubiaceae (Juss): Chomelia obtusa (Cinchonoideae - Guettardeae) and Ixora coccinea (Ixoroideae-Ixorea). Plant Systematics and Evolution 272: 39-48.

Delprete, P.G. 2009. Taxonomic history, morphology and reproductive biology of the tribe Posoquerieae (Rubiaceae,Ixoroideae). Annals of the Missouri Botanical Garden 96: 79-89.

Dickson, W.C. 2006. Integrative plant anatomy. San Diego. HP Harcourt. Academic Press. 533p.

Fahn, A. \& Cuttler, D.F. 1992. Xerophytes. Ed. Gerbrüder Borntraeger, Berlin, 176p.

Foster, A.S. 1949. Practical plant anatomy. Princeton, D. Van Nostrand Company Inc. 228p.

Franklin, G.L. 1945. Preparation of thin sections of synthetic resins and wood-resin composites, and a new macerating method for wood. Nature 155: 51.

Gomes, D.M.S. \& Neves, L.J. 2009. Scanning electron microscopy of the leaf epidermis of Merostachys Spreng. (Poaceae: Bambusoideae). Acta Botanica Brasilica 23: 516-525.

Gomes, D.M.S. 2002. Anatomia foliar de espécies de Merostachys Spreng. (Poaceae:Bambusoideae) no Sudeste Brasileiro. Tese de Doutorado, Museu Nacional, UFRJ. 138p. 
Gomes, D.M.S.; Arruda, R.C.O.; Vieira, R.C. \& Gomes, M. 2000. Anatomia foliar de Bathysa gymnocarpa K. Schum, B. mendonçaei K. Schum, B. cuspidata (St.-Hil.) Hook.f. e B. australis (St.-Hil.) Hook.f. (Rubiaceae) da Mata Atlântica RJ, Brasil. Leandra 15: 59-72.

Haberlandt, G. 1928. Physiological plant anatomy. MacMillian \& Co. Ltd., London. 777p.

Henriques, R.P.B.; Araujo, D.S.D. \& Hay, J.D. 1986. Descrição e classificação dos tipos de vegetação da restinga de Carapebus, Rio de Janeiro. Revista Brasileira de Botânica 9: 173-189.

Horner, H.T.J. \& Whitmoyer, R.E. 1972. Raphide crystal cell development in leaves of Psychotria punctata (Rubiaceae). Journal of Cell Science 11: 339-355.

Jansen, S.; Watanabe, T.; Dessein, S.; Smets, E. \& Robbrecht, E. 2003. A comparative study of metal levels in leaves of some $\mathrm{Al}$-accumulating Rubiaceae. Annals of Botany 91: 657-663.

Jensen, W.A. 1962. Botanical histochemistry principles and pratice. W.H. Freeman and Co., San Francisco. 408p.

Johansen, D.A. 1940. Plant microtechnique. McGrowHill Book Co. Inc, New York. 523p.

Judd, W.S.; Campbell, C.S.; Kellogg, E.A.; Stevens, P.F. \& Donoghue, M.J. 2009. Sistemática vegetal. Um enfoque filogenético. Armed Ed., Porto Alegre. 612p.

Juniper, B.E. \& Jeffre, C. 1983. Plant surfaces. Edward Arnold Pub., London. 93p.

Kocsis, M.; Dárok, J. \& Borhidi, A. 2004. Comparative leaf anatomy and morphology of some neotropical Rondeletia (Rubiaceae) species. Plant Systematics and Evolution 248: 205-218.

Kraus, J.E. \& Arduin, M. 1997. Manual básico de métodos em morfologia vegetal. EDUR, Seropédica, 198p.

Leonhardt, C.; Bueno, O.L.; Busnello A.; Calil, A.C. \& Rosa, R. 2008. Morfologia e desenvolvimento de plântulas de 29 espécies arbóreas nativas da área da bacia hidrográfica do Guaíba, Rio Grande do Sul, Brasil. Iheringia, Série Botânica 63: 5-14.

Luque, R.; Sousa, H.C. \& Kraus, J.E. 1996. Métodos de coloração de azul de Roeser (1972) - modificado - e Kropp (1972) visando a substituição do azul de astra por azul de alcião $8 \mathrm{GS}$ ou $8 \mathrm{GX}$. Acta Botanica Brasilica 10:199-212.

Macias,L.F.N. 1988. Revisãotaxonômica do gênero Posoqueria Aublet (Rubiaceae). Dissertação de Mestrado. Universidade de Campinas, Campinas. 197p.

Mantovani, A. \& Vieira, R.C. 1993/1997. Leaf surface of two understorey shrubs. Rodriguesia 45/46: 7-13.
Mantovani, A.; Gomes, M.; Gomes, D.M.S. \& Vieira, R.C. 1995. Anatomia foliar de Rudgea decipiens Müll.Arg e R. macrophylla Benh (Rubiaceae). Acta Botanica Brasilica. 9: 247-261.

Martinez-Cabrera, D.; Terrazas, T. \& Ocholerena, H. 2009. Foliar and petiole anatomy of tribe Hameliaeae and other Rubiaceae. Annals of Missouri Botanical Garden 96: 133-145.

Metcalfe, C.R. \& Chalk, L. 1950. Anatomy of the Dicotylodons: leaves, stems, and wood in relation to taxonomy - with notes on economic uses. 1 ed. Vol. 1. Clarendon Press, Oxford. 1498p.

Metcalfe, C.R. \& Chalk, L. 1979. Anatomy of the Dicotyledons: systematic anatomy of the leaf and stem. 2 ed. Vol. 1. Oxford University Press, New York. 276p.

Robbrecht, E. \& Manen, J.F. 2006. The major evolutionary lineages of the coffee family (Rubiaceae, angiosperms).Combined analyses(nDNA an cpDNA) to infer the position of Coptosapelta and Luculia, and supertree construction based on rbcL, rps 16, trnL-trnF and atpB rbcL data. A new classification in two subfamilies, Cinchonoideae and Rubioideae. Systematics and Geography of Plants National Botanic Garden 76: 85-146.

Sousa, O.V.; Del Vechio-Vieira, G.; Almeida, B.I.; Miranda, M.A.; Filgueiras, R.C.; Campos, A.C. \& Silvério, M.S. 2007. Efeitos farmacológicos e toxicológicos do extrato de Posoqueria acutifolia Mart (Rubiaceae) em roedores. Revista de Ciências Farmacêuticas Básicas e Aplicadas 28: 51- 56.

Stuessy, T.F. 1990. Plant Taxonomy: the systematic evaluation of comparative data. Columbia University Press, New York. 514p.

van Arendonk, J.J.C.M. \& Poorter, H. 1994. The chemical composition and anatomical structure of leaves of grass species differing in relative growth rate. Plant, Cell and Environment 17: 963-970.

Vieira, R.C. 1994. Considerações sobre o clima e solo da floresta da Tijuca e de Búzios. Cadernos de Geociências 12: 45-50.

Vieira, R.C.; Gomes, D.M. \& Ferraz, C.L.A. 1992. Anatomia foliar de Psychotria nuda Wawra e Psychotria leiocarpa Mart. (Rubiaceae). Hoehnea 19: 185-195.

Wilkinson, H.P. 1979. The plant surface (mainly leaf) Part VII: Epicuticular wax and its morphology. In: Metcalfe, C.R. \& Chalk, L. 1979. Anatomy of the dicotyledons: systematic anatomy of the leaf and stem. 2 ed. Vol. 1. Oxford University Press, New York. 276p. 